\title{
Should National Human Rights Institutions Institutionalise Dispute Resolution?
}

\author{
Lorna McGregor, Rachel Murray, Shirley Shipman* \\ Forthcoming, Human Rights Quarterly 2019
}

\begin{abstract}
The UN has promoted the use of alternative dispute resolution (ADR) by national human rights institutions (NHRIs). This article critically examines this proposition by analysing the three assumptions that underlie it. First, that ADR is an appropriate means by which to resolve human rights disputes; second, that ADR should be provided in institutional form; third, that an NHRI should play a role in the delivery of ADR. We argue that voluntary engagement with ADR is permissible subject to procedural and substantive standards of justice but identify the risk that the offer of ADR by an institution may turn into a de facto mandatory process if not set within a context in which the courts are also accessible. Rather than an outright rejection of a role for ADR in such circumstances, we examine the potential contributions an institution could make to redressing the deficiencies in the access to justice landscape and identify the key factors states and other policymakers should take into account when determining which institution(s) assume a dispute resolution role.
\end{abstract}

\section{Introduction}

Alternative dispute resolution (ADR) is an umbrella term that captures a wide range of processes designed to resolve a dispute or complaint. ${ }^{1}$ It can refer to agreement-based dispute resolution (for example, conciliation, mediation and settlement negotiations) as well as

\footnotetext{
*Lorna McGregor is a Professor in International Human Rights Law at Essex Law School and Director of the Human Rights Centre at the University of Essex. She is a Commissioner on the Equality and Human Rights Commission of Great Britain. This article does not necessarily reflect or represent the views or position of the EHRC. Rachel Murray is Professor of International Human Rights Law at the University of Bristol and Director of its Human Rights Implementation Centre. Dr Shirley Shipman, Principal Lecturer in Law, Oxford Brookes University. This article was written as part of a grant funded by the Nuffield Foundation on The Role of National Human Rights Institutions in Providing Access to Justice (41695) on which the authors of this article were investigators. The authors thank Dr Helene Tyrrell for her research assistance and support. They also thank the many interviewees for their insights and Karen Grayson, Professor Chris Hodges, Professor Christopher McCrudden, Professor Carrie Menkel-Meadow, Dr Nick O’Brien, Dr Thomas Pegram, Professor Linda Reif for their review and comments of this article.
} ${ }^{1}$ SUSAN BLAKE ET AL, A PRACTICAL APPROACH TO ALTERNATIVE DISPUTE RESOLUTION, 5
(2012). 
processes such as arbitration where decisions are reached by third party decision-makers that are not courts. It can be used instead of, prior to, during or following litigation. ADR plays a prominent role in resolving disputes in many jurisdictions, particularly in areas such as commercial arbitration and family mediation. ${ }^{2}$ In Europe, the entry into force of the ADR Directive $^{3}$, the Mediation Directive ${ }^{4}$ and the Online Dispute Resolution Regulation ${ }^{5}$ for consumer disputes has promoted the use of ADR further, including in jurisdictions in which ADR has not previously been used widely.

An emerging area of analysis that has not yet received significant attention in the literature is the use of ADR to resolve human rights complaints. ${ }^{6}$ This is despite the use of ADR to deal with human rights complaints in practice. Agreement-based dispute resolution is regularly used, such as the friendly settlement system offered by regional human rights courts ${ }^{7}$; the settlement of human rights complaints at the national level ${ }^{8}$; and the powers of some ombudspersons, national equality and human rights bodies to use settlement, conciliation or mediation. ${ }^{9}$ Similarly, human rights are included explicitly within the mandate of public sector ombudspersons. ${ }^{10}$ In addition to using agreement-based dispute resolution, the

\footnotetext{
${ }^{2}$ See, for example, country studies in KLAUS HOPF AND FELIX STEFFEK (eds), MEDIATION: PRINCIPLES AND REGULATION IN COMPARATIVE PERSPECTIVE (2013).

${ }^{3}$ Directive 2013/11 on alternative dispute resolution for consumer disputes and amending Regulation (EC) No. 2006/2004 and Directive 2009/22/EC (Directive on consumer ADR), L 165/63.

${ }^{4}$ Directive 2008/52/EC on certain aspects of mediation in civil and commercial matters (Mediation Directive), L $136 / 3$.

${ }^{5}$ EU Regulation 524/2013.

${ }^{6}$ Lorna McGregor, Alternative Dispute Resolution and Human Rights: Developing a Rights-Based Approach through the ECHR, 26(3) EUR. J. INT'L L. 607 (2015) and EJIL Live! Interview available at: http://www.ejil.org/episode.php?episode=21

${ }^{7}$ HELEN KELLER ET AL, FRIENDLY SETTLEMENTS BEFORE THE EUROPEAN COURT OF HUMAN RIGHTS: THEORY AND PRACTICE (2010); Inter-American Commission on Human Rights, Resolution 1/2013, Reform of the Rules of Procedure, Policies and Practices, Revised Rules of Procedure (2013) at VI; Impact of the Friendly Settlement Procedure (2014).

${ }^{8}$ Examples of reported settlements include, 'Compensation to Guantanamo Detainees was 'Necessary' $B B C$ News (16 November 2010) available at: http://www.bbc.co.uk/news/uk-11769509; 'Lieutenant-Colonel Nicholas Mercer says it is 'beyond question' that British soldiers tortured Iraqis' Independent http://www.independent.co.uk/news/uk/home-news/lieutenant-colonel-nicholas-mercer-says-it-is-beyondquestion-that-british-soldiers-tortured-iraqis-a6803281.html; 'Gold Mining Silcosis' available at: https://www.leighday.co.uk/International-and-group-claims/Gold-mining-silicosis-(1)

${ }^{9}$ See, for example, the practice of the Australian Human Rights Commission, the Human Rights Ombudsman of Bosnia and Herzegovina, the Canadian Human Rights Commission and the Netherlands College Voor de Rechten Van de Mens.

${ }^{10}$ LINDA REIF, THE OMBUDSMAN, GOOD GOVERNANCE AND THE INTERNATIONAL HUMAN RIGHTS SYSTEM (2004). See, Lorna McGregor, Rachel Murray, Shirley Shipman, Hélène Tyrrell, National Human Rights Institutions in Europe and Dispute Resolution: A Mapping (April 2017) available at: https://www.essex.ac.uk/hrc/practice/access-to-justice.aspx (hereinafter NHRI and Dispute Resolution Mapping Report).We adopt the term 'ombudsperson' in this paper to reflect a gender-neutral formulation of the term. For further discussion on the use of the term see Varda Bondy and Margaret Doyle, 'Manning' the Ombuds Barricades UKAJI Blog (2015).
} 
investigations and issuance of recommendations by ombudspersons could be characterised as a form of ADR for human rights complaints. ${ }^{11}$ Such characterisation will depend on whether the purpose of the investigation is aimed at securing a remedy for the complainant (in which case it may be a form of ADR) or is only about addressing the underlying practice, policy or behaviour of the respondent (in which case it will not). ${ }^{12}$

The United Nations (UN) and other international bodies have also promoted the use of ADR by National Human Rights Institutions (NHRIs). ${ }^{13}$ NHRIs are defined as institutions with a mandate to promote and protect human rights and that have been awarded $\mathrm{A}, \mathrm{B}$, or $\mathrm{C}$ status by the UN International Coordinating Council (ICC) - or the Global Alliance of National Human Rights Institutions (GANHRI) as it has recently been renamed. ${ }^{14}$ NHRIs take a range of forms including, 'commissions; ombudsman institutes; hybrid institutions; consultative and advisory bodies; research institutes and centres; civil rights protectors; public defenders; and parliamentary advocates' or a hybrid of one or more ${ }^{15}$ (such as an equality body, traditional human rights commission and ombudsperson organised under an umbrella institution) which is common in Europe. ${ }^{16}$ The 2008 Nairobi Declaration adopted by the Ninth International Conference of National Institutions for the Promotion and Protection of Human Rights recommends that NHRIs may 'settl[e] the case through conciliation and mediation, thereby relieving the existing case-load of courts' ... as well as seeking 'informal legal redress mechanisms through conciliation or through binding decisions' ${ }^{17}$

\footnotetext{
${ }^{11}$ Chris Gill and Carolyn Hirst, Defining Consumer Ombudsmen: A Report for Ombudsmen Services (2016); Nick O'Brien, What Future for the Ombudsman, POLITICAL QUARTERLY (2015); Richard Kirkham, The Ombudsman, Tribunals and Administrative Justice Sector: A 2020 Vision for the Ombudsman Sector JOURNAL OF SOCIAL WELFARE AND FAMILY LAW 103 - 114 (2016).

${ }^{12}$ Meg Brodie, Uncomfortably Truths: Protecting the Independence of National Human Rights Institutions to Inquire 38 UNIVERSITY OF NEW SOUTH WALES LAW JOURNAL 1215 (2015).

${ }^{13}$ United Nations OHCHR, National Human Rights Institutions: History, Principles, Roles and Responsibilities, Professional Training Series No 4, 93 (2010); Commonwealth Secretariat, Comparative Study on Mandates of National Human Rights Institutions in the Commonwealth 27 (2007); Ninth International Conference of National Institutions for the Promotion and Protection of Human Rights Nairobi, Kenya, 21-24 October 2008, The Nairobi Declaration (24 October 2008).

${ }^{14}$ The ICC was renamed GANHRI at the $29^{\text {th }}$ General Meeting of the ICC in March 2016: http://nhri.ohchr.org/EN/ICC/GeneralMeeting/29/Pages/Default.aspx (last visited 3 January 2017). As the ICC has only recently been renamed, we use the acronym 'ICC/GANHRI' in this article to avoid confusion.

${ }^{15}$ ICC, ICC SCA General Observations as adopted in Geneva in May 2013 (2013).

${ }^{16}$ Neil Crowther and Colm O'Cinneide, Bridging the Divide? Integrating The Functions of National Equality Bodies and National Human Rights Institutions in The European Union (2013).

${ }^{17}$ Nairobi Declaration supra note 13; see also, Commonwealth Secretariat, supra note 13 at 24; EU Agency for Fundamental Rights, Bringing Rights to Life: The Fundamental Rights Landscape of the European Union 9 (2012).
} 
The article draws on the findings of a project funded by the Nuffield Foundation which examined the role NHRIs within Europe ${ }^{18}$ already play in ADR and the reasons underpinning the lack of such a mandate for others. ${ }^{19}$ Focusing on NHRIs enabled us to capture a manageable sample of bodies at the national level. However, there are many more institutions in Europe with a human rights mandate than those that have either A, B or C status with the ICC/GANHRI. This may be because their mandate is narrower, for example, an equality body that focuses on equality and non-discrimination rather than all human rights ${ }^{20}$ or an ombudsperson that handles human rights complaints but does not have a wider promotional mandate. While our research did not examine the practice of these bodies comprehensively, our findings are likely to be relevant to them.

This article seeks to contribute to the emerging scholarship on ADR for human rights complaints by critically examining the proposition that NHRIs (or similar bodies at the national level such as equality bodies) should provide a form(s) of ADR. We do so through an analysis of three assumptions underlying the promotion of such a role. The first assumption is that the means by which human rights disputes are resolved can and should be wider than judicial resolution. In Part 1, we argue that the starting point for considering how a dispute should be resolved should be to establish the aim(s) of pursuing a complaint and whether courts and/or ADR processes are best suited to achieving that aim. In doing so, we caution against viewing ADR as a monolithic practice but rather suggest that it should be seen as an umbrella term to capture a wide range of processes with different characteristics and therefore different advantages and potential challenges for the resolution of human rights disputes.

Within this assessment, one key distinction, in our view, is whether engagement with ADR is mandatory or voluntary. We suggest that a mandatory requirement to engage with ADR is likely to face challenges under international human rights law (IHRL). However, voluntary

\footnotetext{
${ }^{18}$ The NHRIs were identified using the Directory of Institutions within Europe provided by the ICC/GANHRI http://nhri.ohchr.org/EN/Contact/NHRIs/Pages/Europe.aspx and the member institutions listed on the European Network of NHRIs (ENNHRI) website - http://www.ennhri.org/List-of-members. The NHRIs included on these lists and their ICC/GANHRI accreditation status changed slightly over the course of the project, for example, where an NHRI was no longer accredited by the ICC/GANHRI. The GANHRI list includes 50 institutions, nine of which do not have an accreditation status listed. ENNHRI has 40 members, eight of which do not have ICC/GANHRI accreditation according to the ENNHRI website.

${ }^{19}$ See, NHRI and Dispute Resolution Mapping Report.

${ }^{20}$ EU Fundamental Rights Agency, National Human Rights Institutions in the EU Member States: Strengthening the Fundamental Rights Structure in the EU (Publications Office of the European Union 2010), 11. Crowther and O'Cinneide, Bridging The Divide?id at 5.
} 
engagement may be permissible and potentially advantageous to certain complainants or disputes, depending on the aim(s) of pursuing a complaint. However, even where an ADR process aligns with such aims, the process should embed procedural and substantive standards of justice. Consideration of what these standards should look like and embedding them in practice is only beginning to be addressed and, until resolved, may be a central limitation to the use of ADR for human rights complaints.

The second assumption is that ADR should be provided in institutional form. In Part 2, we examine the advantages offered by the institutionalisation of ADR as well as the impact institutionalisation may have on the perceived voluntariness of engagement with the process, particularly in contexts in which the courts are difficult or too expensive to access. This may mean that ADR, as provided by an institution such as an NHRI, becomes the main means available for resolving human rights complaints rather than one of a number of options. This could be seen as transforming ADR from a voluntary into a de facto mandatory process. This be an unintended consequence of what otherwise might reflect an attempt to increase access to justice and pluralise the options for dealing with human rights complaints. Rather than an outright rejection of a role for ADR in such circumstances, we examine the potential contributions an institution could make to redressing the deficiencies in the access to justice landscape.

The third assumption is that an NHRI or similar body should play a role in the delivery of this wider conception of access to justice which we assess in Part 3. This assumption raises questions about the purpose of such bodies and the best strategic use of their resources, often in a context in which they are expected to deliver a large number of functions with significant resource constraints. This article therefore addresses interconnected debates on access to justice and the institutional frameworks for the promotion and protection of human rights within a state that have received relatively little attention to date. It provides a framework and diagnostic tool for states, other policy makers, international organisations, NHRIs and similar bodies when considering whether to employ ADR for human rights disputes and whether to provide it in institutional form.

\section{Assessing the Compatibility of ADR with Human Rights Complaints}


In order to assess the normative desirability of NHRIs and similar institutions playing a role in ADR, the baseline question of whether ADR is an appropriate way in which to deal with human rights complaints must be addressed. There are two dimensions to this question. The first dimension is whether IHRL permits the use of ADR to resolve human rights complaints. Even if considered permissible, the second dimension to the question is whether ADR is a desirable means by which to resolve human rights complaints. As ADR varies between and within each process, a simple or uniform answer to this question is not easily reached as it will depend on the complainant, the nature of the human rights violation, the characteristics of the particular ADR process and the objective(s) of resolving the dispute. Therefore, it is not possible to assert that all ADR processes are (un)desirable for resolving human rights disputes. Rather, in our view, each form of dispute resolution (including courts) needs to be assessed against the purpose(s) of pursuing a human rights complaint.

\subsection{Is ADR a Permissible Means to Resolve Human Rights Disputes?}

Two key issues affect the permissibility of ADR: first, the voluntariness of engagement with the process and second, the impact engagement with an ADR process has on the duty to investigate allegations of human rights violations, where applicable.

\subsubsection{Voluntariness of the Process}

Where engagement with the process is voluntary and results in a non-binding outcome (which is the case with agreement-based ADR and most investigations conducted by ombudspersons), IHRL is unlikely to prohibit engagement with ADR provided two conditions are met. First, the European Court of Human Rights (ECtHR) has found that waiver of the right of access to a court is permissible provided the individual provides free and informed consent, no coercion or fraud is involved and the waiver is clear and unequivocal. ${ }^{21}$ Second, where an institution, such as an ombudsperson, issues recommendations on a complaint, IHRL is also likely to require the independence and impartiality of that body. For example, the ECtHR has previously found that it may not be

\footnotetext{
${ }^{21}$ See, McGregor, supra note 6 (discussing the case-law of the European Court of Human Rights on these points).
} 
possible to waive the right to an impartial tribunal. ${ }^{22}$ The general permissibility of voluntary engagement with ADR appears logical given that the complaint ultimately belongs to the complainant and, as discussed below, some complainants may wish to pursue a form of ADR as a first step, or instead of litigation, depending on their objectives in pursuing a complaint.

By contrast, the position with mandatory requirements to engage with ADR may be different. Mandatory ADR can take two forms: first, parties may be required to engage in the ADR process. In the case of agreement-based dispute resolution, they would retain the choice over whether or not to reach an agreement to resolve the dispute and the nature of that resolution. Where a decision is made by a third party, such as an ombudsperson, the decision would be non-binding on both parties or only binding on the respondent, meaning that the parties (or the complainant in the latter scenario) would retain the choice of whether to comply with the decision. The second form of mandatory ADR is where both engagement with the process and compliance with the findings of a third party decision-maker (such as an arbitrator) are required. In general, opposition to mandatory ADR underscores the absence of autonomy or consent of the parties as one of the main attributes of ADR. By extension, mandatory ADR would circumvent the right of access to a court as well as potentially undermine the public resolution of disputes with a public value, such as human rights, where confidentiality is part of the process (which as discussed below can apply to some but not all ADR processes). ${ }^{23}$ While these risks are most pronounced with the second form of mandatory ADR, scholars such as Genn argue that they may be as applicable in the first form where more subtle pressures to reach agreement or comply may apply. ${ }^{24}$

For human rights violations specifically, the only source that addresses the mandatory use of ADR explicitly is the Council of Europe's Convention on Preventing and Combating Violence against Women and Domestic Violence. It prohibits mandatory ADR even where the parties have control over the outcome, for example mandatory mediation. ${ }^{25}$ The question arises whether this prohibition might apply to human rights complaints more broadly. Two

\footnotetext{
${ }^{22}$ See, Shirley Shipman, Waiver: Canute against the Tide, 32 CIVIL JUSTICE QUARTERLY 470 (2013)

(discussing the relevant European Court of Human Rights jurisprudence on the limitations to waiver).

${ }^{23}$ Examples of mandatory arbitration, for example, include consumer, housing and employment contracts in the US whereby a mandatory binding arbitration clause is written into the contract. National Association of Consumer Advocates at http://www.consumeradvocates.org/for-consumers/arbitration accessed on 8 June 2017 ${ }^{24}$ Hazel Genn, What is Civil Justice For? Reform, ADR and Access to Justice, 24 YALE JOURNAL OF LAW AND HUMANITIES 397, 404 (2012).

${ }^{25}$ Article 48(1).
} 
possible interpretations are available in this respect. First, on a narrow reading, this prohibition might be interpreted to extend to all human rights violations involving an allegation of violence or criminality, such as torture and other forms of cruel, inhuman or degrading treatment or punishment, unlawful or arbitrary killings, enforced disappearance, slavery, servitude and trafficking in human beings. Second, the prohibition might also be read to extend to any human rights complaint where, by virtue of the (alleged) human rights violation, the complainant is perceived to be in a position of vulnerability. This interpretation aligns with critiques within the ADR literature of the use of mandatory ADR in cases where domestic violence has either been proven or alleged even if not the subject of the mediation process, on the grounds that the power imbalance between the parties may result in an unfair process and/or outcome. ${ }^{26}$

What is less clear is whether the prohibition of mandatory ADR would extend to all forms of human rights complaints, particularly where parties retain some form of autonomy over the outcome. Both the Australian and Canadian Human Rights Commissions have a mandatory model of conciliation for discrimination complaints. ${ }^{27}$ In the UK, the Children and Families Act requires the consideration of mediation prior to bringing a claim before the Special Educational Needs and Disability Tribunal. ${ }^{28}$ Both examples are of mandatory requirements to engage in the process but are not mandatory in outcome. Presumably, the same arguments about vulnerability and perceived feelings of pressure to settle might apply to these models. However, further debate and analysis are needed to unpack where the lines between the permissibility and impermissibility of mandatory ADR with a voluntary outcome might be drawn. Only making a distinction based on the 'seriousness' of the complaint would appear too blunt and may risk a bifurcated approach to mandatory agreement-based processes that undermines the indivisibility of human rights. As discussed further below, other important factors may relate to the public importance of the underlying complaint and the extent to which power imbalances can be addressed within the process.

\footnotetext{
${ }^{26}$ For example, see, Trina Grillo, The Mediation Alternative: Process Dangers for Women 100(6) YALE LAW JOURNAL 1545-1610 (1991); Leah Wing, Mediation and Inequality Reconsidered: Bringing the Discussion to the Table, 26(4) CONFLICT RESOLUTION QUARTERLY 383-404 (2009); Linda Mulcahy, The Possibilities and Desirability of Mediator Neutrality: Towards an Ethic of Partiality, 10(4) SOCIAL AND LEGAL STUDIES 505-527 (2001); Richard Delgado et al, Fairness and Formality: Minimising the Risk of Prejudice in Alternative Dispute Resolution, WISCONSIN LAW REVIEW 1359-1404 (1985).

${ }^{27}$ See, Complaints Page of Australian Human Rights Commission available at: https://www.humanrights.gov.au/complaint-information and 'What Can I Expect'? Canadian Human Rights Commission, http://www.chrc-ccdp.gc.ca/eng/content/what-can-i-expect (on the conciliation process)

${ }^{28}$ Section 55 .
} 


\subsubsection{Impact on the Duty to Investigate}

The second issue on the permissibility of ADR for human rights disputes relates to how the duty to investigate, where applicable, is affected by engagement with ADR. Where allegations of serious or gross human rights violations such as torture, killings, enforced disappearance or trafficking in human beings are made, states are under an obligation to carry out a full and thorough investigation capable of identifying and punishing those responsible for the violation under IHRL. ${ }^{29}$ The question arises whether the complainant can agree that an investigation is not necessary through agreement-based ADR or whether an investigation by a body like an ombudsperson can fulfil the duty to investigate, thereby removing the requirement for the attorney general or state prosecutor to investigate. This question has not yet been addressed by an international or regional human rights tribunal. However, it is difficult to conceive how parties could agree to dispense with an investigation given that the duty to investigate is an independent procedural obligation on the state which presumably a complainant cannot unilaterally remove. In such a situation, the duty to investigate would not necessarily prevent the parties from attempting to resolve the civil dimension to the dispute, for example, by agreeing on an appropriate remedy and reparation for the victim and any wider policy or practice that required change. However, it seems unlikely that such an agreement could override the state's duty to investigate.

The nature of the process as voluntary or mandatory and the impact on the duty to investigate, where applicable, set the baseline for the permissibility of ADR in relation to human rights claims. In our view, they are central points of departure for policymakers considering the use - and in particular, the institutionalisation - of ADR for human rights disputes. Provided these conditions are met, the next question is whether ADR processes constitute an appropriate or desirable means for resolving human rights claims.

\subsection{Is ADR a Desirable Means to Resolve Human Rights Disputes?}

\footnotetext{
${ }^{29}$ See Case of Velásquez Rodríguez v Honduras IACtHR Series C 4 (1988); 74/92, Commission Nationale des Droits de l'Homme et des Libertés v Chad, African Commission on Human and Peoples Rights (11 October 1995); and 245/02, Zimbabwe Human Rights NGO Forum v Zimbabwe, African Commission on Human and Peoples Rights (15 May 2006), at para 153; McCann and Others $v$ United Kingdom Application No 18984/91, Merits and Just Satisfaction, European Court of Human Rights (27 September 1995), at para 161.
} 
In this section, we identify the possible contributions of certain ADR processes to human rights and ask whether the concerns expressed about aspects of certain ADR processes can be overcome.

\subsubsection{Potential Contribution of ADR Processes to Dealing with Human Rights Complaints}

A number of possible objectives can be identified in relation to human rights claims. Under IHRL, where an individual has an arguable claim that his or her human rights have been violated, he or she has the right to access justice and, where a violation is found, to full and effective reparation. Like public international law more broadly, the primary form of reparation is restitution. However, since this is rarely fully achievable in relation to human rights claims, reparation also encompasses compensation, rehabilitation, satisfaction and guarantees of non-repetition. ${ }^{30}$ These five forms of reparation focus on justice and a remedy and reparation for the individual(s) affected. They also respond to wider objectives of accountability, public acknowledgment of wrongdoing and assurance that the violations will not be repeated. This may include holding individuals to account through criminal responsibility, where required, as well as a focus on how institutions and arms of the state operate and whether systemic or structural change is needed in order to ensure that violations are not repeated. It is often assumed that courts are the most appropriate forum for dealing with human rights claims. However, when set against these potential objectives, courts may not always be best placed or fully able to address all of the objectives, particularly guarantees of non-repetition. Therefore there may be a role for ADR, instead of, or in conjunction with the courts depending on the particular case.

Some complainants may seek public acknowledgment of what happened to them by a third party neutral. The social status of courts may be important in this regard both for the complainant (having their 'day in court') as well as from a compliance perspective as certain respondents may only recognise court judgments. Equally, it may also be possible for bodies such as an arbitration tribunal or an ombudsperson to fulfil this function depending on the

\footnotetext{
${ }^{30}$ United Nations Basic Principles and Guidelines on the Right to a Remedy and Reparation for Victims of Gross Violations of International Human Rights Law and Serious Violations of International Humanitarian Law, Adopted and proclaimed by General Assembly resolution 60/147 of 16 December 2005.
} 
regard with which they are held. ${ }^{31}$ Other complainants, however, may not wish to go through the formality and unpredictability of litigation. ${ }^{32}$ This may be particularly the case in situations such as torture in which the allegations have already been criminally investigated. In such cases, the complainant may prefer to use the results of the criminal investigation as the basis for a settlement negotiation or mediation. Others may wish to engage with the agency or alleged perpetrator, making conciliation or mediation a more attractive option. Parties may also be attracted to ADR processes, particularly agreement-based processes as they can provide parties with greater self-determination and autonomy, ${ }^{33}$ empowering them to shape and 'control the outcome'. 34

The nature of the remedies available through the courts and ADR processes may also be relevant for the choice of process. The powers of many national courts may be limited to issuing declaratory judgments or compensation awards ${ }^{35}$ meaning that they cannot provide the full forms of reparation envisaged by the UN Basic Principles. By contrast, ADR processes may provide greater scope for securing tailored remedies on restitution (or partial restitution), rehabilitation and satisfaction through agreement-based processes as well as the findings of ombudspersons, depending on their mandate. ${ }^{36}$

Agreement-based processes are often characterised as focused on the interests of the parties only. ${ }^{37}$ It may be difficult for individual mediators or conciliators or external mediators hired by an institution to identify wider issues represented by the complaint and thereby seek system change since they may not see patterns in complaints or have sufficient points of comparison. ${ }^{38}$ However, some scholars have challenged the proposition that ADR processes

\footnotetext{
${ }^{31}$ Susan Sturm and Howard Gadlin, Conflict Resolution and Systemic Change, 1 JOURNAL OF DISPUTE RESOLUTION 1, 47 (2007).

${ }^{32}$ Interview 60. Thomas Main, ADR: The New Equity, 74 UNIVERSITY OF CINCINNATI LAW REVIEW 329 (2005).

${ }^{33}$ Isabelle Gunning, Diversity Issues in Mediation: Controlling Negative Cultural Myths, JOURNAL OF DISPUTE RESOLUTION 55 (1995).

${ }^{34}$ Dominique Allen, Against Settlement? Owen Fiss, ADR and Australian Discrimination Law 10 INTERNATIONAL JOURNAL OF DISCRIMINATION AND THE LAW 191. 195 (2009).

${ }^{35}$ Michael Moffitt, Three Things to Be Against ("Settlement" Not Included) 78 FORDHAM LAW REVIEW 1203, 1212 (2009); Lisa Bernstein, Understanding the Limits of Court-Connected ADR: A Critique of Federal Court-Annexed Arbitration Programs 141 UNIVERSITY OF PENNYSYLVANIA LAW REVIEW 2169, 2239 (1993).

${ }^{36}$ Interview 39; Carrie Menkel-Meadow, Whose Dispute Is It Anyway?: A Philosophical and Democratic Defense of Settlement (In Some Cases) 83 GEORGETOWN LAW JOURNAL 2663 (1995); Moffitt, id; Bernstein, id.

${ }^{37}$ Sturm and Gadlin, supra note 31 at 8 .

${ }^{38} I d$ at 42 .
} 
are incapable of dealing with strategic issues, accountability and justice. ${ }^{39}$ Gadlin and Sturm, for example, argue that certain ADR processes counter the tendency to 'segregate individual casework from systemic interventions aimed at addressing policy issues, examining recurring problems, or redesigning organizational systems'. They do so by integrating 'systemic thinking into individual casework, and individual cases into the project of understanding and addressing systemic concerns' through what they call 'root cause analysis' ${ }^{40}$ Gadlin and Sturm suggest that certain ADR processes can 'produce systemic changes that adjudication cannot achieve, and can thus solve public problems and generate public values'. ${ }^{41}$ In consumer dispute resolution, Hodges emphasises the role that ombudspersons play in providing advice and dispute resolution but also, if designed with systemic issues in mind, in aggregating data and feeding it back in order to 'operat[e] as early warning and monitoring functions to support oversight by public regulatory enforcement bodies' ${ }^{42}$ Institutions such as ombudspersons that offer a form(s) of ADR as a means of resolving a complaint may therefore be well-placed to identify systemic issues and address them through findings as well as securing a remedy for the individual. ${ }^{43}$ Indeed, annual reports by ombudspersons with human rights' mandates often identify patterns in complaints on particular issues. ${ }^{44}$

\subsubsection{Concerns about ADR}

Notwithstanding the potential alignment of certain ADR processes with the purpose(s) of the pursuit of a human rights complaint, there may be resistance to the employment of some or all forms of ADR for human rights complaints both from the perspective of the complainant and the public-interest.

For the complainant, the claims of self-determination, control and the ability to shape and devise creative remedies are often challenged. In agreement-based processes, commentators highlight the risk that the complainant is placed in a position of vulnerability with the

\footnotetext{
39 Thomas Shaffer and Andrew McThenia, For Reconciliation, 94 YALE LAW JOURNAL 1660 (1984).

${ }^{40}$ Sturm and Gadlin supra note 31 at 4.

${ }^{41}$ Id at 4.

${ }^{42}$ Chris Hodges, 'Consumer Ombudsmen: Better Regulation and Dispute Resolution' 15(4) JOURNAL OF ACADEMY OF EUROPEAN LAW 593 - 608 (2015)

${ }^{43}$ Id at 40.

${ }^{44}$ For example, Institution of Human Rights Ombudsman of Bosnia and Herzegovina, 2015 Annual Report on the Results of the Activities of the Institution of the Human Rights Ombudsman of Bosnia and Herzegovina (March 2016). For illustration of this point, See, NHRI and Dispute Resolution Mapping Report.
} 
potential that the process and/or the outcome may prove harmful or unfavourable to him or her. ${ }^{45}$ Power imbalance between the parties, which is particularly acute in human rights cases, lies at the heart of these concerns. Part of these concerns may relate to the resources that the more powerful party, such as a state or business, may be able to invest in the process. ${ }^{46}$ Subtler dynamics of power imbalance may also result in the complainant feeling compelled to settle out of concern that he or she will not be believed in court, regardless of the strength of the case or evidence. ${ }^{47}$ The perceived advantages of ADR processes will also be shaped by the responsiveness and willingness of the respondent to engage and comply with agreements and decisions and the types of conditions they attach to the process, such as confidentiality.

While the literature is less well-developed on the risks to the complainant when complaints are handled by an ombudsperson, similar concerns may arise. The argument might be made that any inequality of arms or power imbalance is overcome by the involvement of the ombudsperson. ${ }^{48}$ However, concerns have been raised that once the complaint is made to the ombudsperson, the complainant may be left out of the process and therefore have no opportunity to influence or participate in the determination of remedies proposed either in settlement negotiations or a formal investigation. ${ }^{49}$ This may be particularly pronounced if the ombudsperson is required to act in the public interest, raising 'interesting questions about who 'owns' the complaint and who decides whether they are satisfied with the proposed settlement' or whether the complaint should still be investigated. ${ }^{50}$ This critique is layered on to the potential for a lack of transparency and openness in how the investigation is conducted and the nature of discussions with the respondent. ${ }^{51}$

To the extent that the dispute resolution process is expected to contribute to accountability and justice for human rights violations, concerns may be raised where confidentiality or a

\footnotetext{
${ }^{45}$ ROBERT A BARUCH BUSH \& JOSEPH FOLGER, THE PROMISE OF MEDIATION; THE TRANSFORMATIVE APPROACH TO CONFLICT 13-15, 41-84 (2005).

${ }^{46}$ Owen Fiss, Against Settlement, 93 YALE LAW JOURNAL 1073, 1076 (1984).

${ }^{47}$ Noel Semple, Mandatory Family Mediation and the Settlement Mission: A Feminist Critique, 24 CANADIAN JOURNAL OF WOMEN AND THE LAW 207 (2012); Simon Roberts, Alternative Dispute Resolution and Civil Justice: An Unresolved Relationship, 56 MODERN LAW REVIEW 452, 462 (1993). ${ }^{48}$ TREVOR BUCK, RICHARD KIRKHAM \& BRIAN THOMPSON, THE OMBUDSMAN ENTERPRISE AND ADMINISTRATIVE JUSTICE 37 (2011).

${ }^{49} I d$ at 43.

${ }^{50}$ Margaret Doyle, Varda Bondy \& Carolyn Hirst, The Use of Informal Resolution Approaches by Ombudsmen in the UK and Ireland: A Mapping Study 13 (2014).

${ }^{51}$ Richard Thomas, Jim Martin \& Richard Kirkham, External Evaluation of the Local Government Ombudsman in England, 29 (2013).
} 
lack of publicity attaches to the process. Agreement-based processes are typically confidential and therefore any admission of wrongdoing and the terms of the agreement will not be publicised unless both parties agree, ${ }^{52}$ leading to the argument that ADR undermines accountability and justice. ${ }^{53}$ Where they are confidential, the Australian Human Rights Commission, for example, produces a case register of anonymised cases to demonstrate the types of cases they receive and how they are dealt with. ${ }^{54}$ While the findings of an ombudsperson are not usually confidential, they are not always published, although the same point can be made about courts in many countries. ${ }^{55}$

Further concerns have been raised about the development of the law and jurisprudence through ADR processes. ${ }^{56}$ For example, the mandatory inclusion of conciliation in the mandate of the Australian Human Rights Commission combined with the confidential nature of conciliation was originally critiqued for its impact on the development of discrimination law. ${ }^{57}$ Ombudspersons may be subject to similar criticisms in addition to the argument that they do not create precedent or certainty in the law in the same way as a judicial finding is meant to. ${ }^{58}$ Concerns are also raised about the extent to which agreement-based processes and ombudspersons take into account the law, including IHRL, ${ }^{59}$ although this very much depends on the mandate, training and approach of the third party and practice of the ombudsperson.

A failure to apply and develop the law is a significant risk, particularly where national courts do not have an established practice of engaging with IHRL in their judgments. This could have the dual result of a lack of clarity on behalf of ADR providers on the parameters of the law and stagnation in the development and implementation of IHRL at the national level. The

\footnotetext{
52 Article 7 European Mediation Directive (Directive 2008/52 on certain aspects of mediation in civil and commercial matters); Article 17(4) ADR Directive (2013/11 on alternative dispute resolution for consumer disputes). Interviews 16, 17, 12, 21, 39, 60 and 63.

${ }^{53}$ Sturm and Gadlin supra note 31.

${ }^{54}$ Australian Human Rights Commission, Conciliation Register, available at: https://www.humanrights.gov.au/complaints/conciliation-register

55 See, Lorna McGregor, Rachel Murray and Shirley Shipman, Developing Bespoke Standards of Justice for Ombudspersons Dealing with Human Rights Complaints forthcoming 2018. (equally noting that, a number of NHRIs, particularly ombudspersons, publish all or a selection of their decisions).

${ }^{56}$ Harry Edwards, Alternative Dispute Resolution: Panacea or Anathema?, 99 HARVARD LAW REVIEW 668 (1985).

57 Allen, supra note 34.

${ }^{58}$ Richard Kirkham and Philip Wells, Evolving Standards in the Complaints Branch, 36(2) JOURNAL OF SOCIAL WELFARE AND FAMILY LAW, 190-207, 196 (2014).

${ }^{59}$ Richard Kirkham, Human Rights and the Ombudsmen - 2005-06, 30(1) JOURNAL OF SOCIAL WELFARE AND FAMILY LAW 75, 77 (2008).
} 
implementation of economic, social and cultural rights is a good illustration of this point. While the justiciability of economic, social and cultural rights is now well established in international law, many states have not changed their domestic practice to enable access to courts. ${ }^{60}$ Many of these claims are therefore typically dealt with by ombudspersons. While ombudspersons may provide an avenue for accessing justice where it is not otherwise available, the risk also arises that they do not identify the rights-dimension to such cases particularly where the relevant IHRL has not been implemented and embedded in domestic judicial practice, meaning that the claims may be treated as less serious than they are. ${ }^{61}$ Equally, the converse may be true that in states in which the courts do not explicitly apply IHRL, it may be ombudspersons or similar bodies that ensure the protection of rights, particularly when they have an explicit human rights mandate. Therefore, generalisations cannot easily be made.

\subsubsection{Can the Concerns be Resolved?}

Acknowledging these critiques, it is necessary to assess whether they should be read to mean that the use of ADR processes for human rights complaints is prohibited; whether they are expressions of normative opposition to their use; or whether they make a claim on how ADR should operate in the human rights realm. Courts have not yet been called upon to determine whether ADR is compatible with remedies for alleged violations of IHRL. The practice of ADR is also diffuse and is not bound by a common set of standards or expectations. Moreover, there are very few empirical studies that establish whether ADR contributes positively to the goals of human rights dispute resolution in practice. However, given that ADR is already used to resolve human rights claims, continues to be promoted and, as already discussed, can offer particular advantages to complainants, it is important to develop responses to the critiques. Here we suggest that such responses should focus on substantive and procedural justice questions.

The ECtHR requires that ADR is 'attended by minimum safeguards commensurate to its importance'. ${ }^{62}$ However, it has not clarified what these safeguards look like in human rights cases. At the moment, the general lack of procedural justice standards attached to agreement-

\footnotetext{
${ }^{60}$ MALCOLM LANGFORD ET AL (EDS), SOCIAL RIGHTS JUDGMENTS AND THE POLITICS OF COMPLIANCE: MAKING IT STICK (2017).

${ }^{61}$ Edwards, supra note 56 at 679.

${ }^{62}$ ECtHR Osmo Suovaniemi and others v. Finland Appl. $31737 / 96$ (Judgment of 23 February 1999).
} 
based processes and complaints-handling by ombudspersons means that there is the potential for significant variations in the quality of justice in process and outcome. As set out above, serious risks can arise for complainants in ADR cases which are particularly acute when dealing with human rights. In certain situations, this will mean that ADR is unsuitable, even if voluntary, although the lines and guidance on how to make such a determination are unclear. In other situations, the way in which the ADR process is structured and conducted may mitigate these risks, enabling the complainant to access the opportunities and attributes of certain ADR processes. As noted above, an ADR process in which the provider (such as an ombudsperson) can investigate the complaint may remove some of the power imbalance as the complainant will be in a stronger negotiating position following an investigation on the facts. ${ }^{63}$ The role of the ADR provider may also be critical in identifying and addressing any signs of power imbalance. Much more analysis is needed, therefore, into the standards of justice in ADR without conflating ADR processes with each other or with courts. Such analysis should include whether existing standards within IHRL, such as procedural justice and equality of arms, can be tailored and adapted for ADR processes without making them slower or more expensive than they should be as such an approach would risk undermining the ADR process completely.

In a separate article, we analyse the standards of justice needed in greater depth and propose frameworks for agreement-based processes and for ombudspersons. Our proposals do not attempt to conflate ADR processes with each other or with courts. Rather, they seek to identify existing standards within IHRL such as procedural justice and equality of arms and assess the extent to which they can be tailored and adapted for ADR processes without making them slower or more expensive than they should be as such an approach would risk undermining the ADR process completely. ${ }^{64}$

Beyond process standards, a significant gap in research that requires attention is the substantive requirements of ADR in addressing concerns of accountability and justice. The UN Office of the High Commissioner for Human Rights has found that in any settlement, conciliation or mediation agreement, the public interest should be reflected. It distinguishes between 'early resolution' and ADR once the institution has conducted some form of

\footnotetext{
${ }^{63}$ Buck, Kirkham and Thompson supra note 48 at 37 (citing O'Brien).

${ }^{64}$ For a more detailed discussion of the standards required, see Shirley Shipman, Lorna McGregor and Rachel Murray, 'Human Rights Claims, Power Imbalances and Standards of Justice for Agreement-Based Dispute Resolution' forthcoming Civil Justice Quarterly.
} 
investigation. 'Early resolution' is characterised as a situation where no investigation into the allegations has taken place and the dispute resolution process may therefore focus only on the interests or needs of the parties. By contrast, once an investigation has taken place and the institution has 'amassed evidence, and will have some basis for taking a position on the strength of the allegation and, consequently, a rights-based perspective that is informed by the evidence and that determines the public interest at stake. To adopt a purely interest-based approach in those circumstances would be to ignore the evidence at hand. ${ }^{65}$ However, it does not clearly define what the public interest means in such circumstances and how it is incorporated into the recommendation or settlement agreement. This may vary depending on the nature of the dispute resolution process. For example, a private settlement negotiation may be subject to different standards and demands than a human rights ombudsperson.

In short, at least in relation to voluntary engagement with ADR processes, there does not appear to be a prohibition on the use of ADR, provided it is not used as a means to evade the obligation to carry out a criminal investigation into the complaint, where applicable. Moreover, in some cases, ADR may be preferable to the complainant and provide greater opportunities for the construction of creative and tailored remedies that potentially are able to identify and address systemic human rights problems. However, even where ADR is considered to offer advantages for the complainant, effective procedures and safeguards will have to be in place to redress any power imbalances and to protect the complainant in both the process and outcome and this remained an underdeveloped area.

\section{Institutionalising ADR}

Having determined the permissibility of voluntary engagement with ADR for human rights complaints in certain situations subject to the conditions set out in Part 1, the next question is whether ADR processes should be offered in institutional form as has been recommended by bodies such as the UN. A specialised institution may not be necessary for all forms of ADR as legal representatives can, in theory, carry out settlement negotiations. In most, if not all, jurisdictions, some mediation and conciliation services may be available, even if not specialised in human rights. Equally, institutionalising agreement-based dispute resolution may have certain advantages, such as increasing awareness and accessibility to ADR

\footnotetext{
${ }^{65}$ OHCHR report, supra note 13 at 93.
} 
processes; and the risks and current lack of uniform practice on substantive and procedural standards of justice may be more easily addressed within an institution. This is both because of the ability to concentrate expertise and develop experience and standards within an institution as well as the public engagement and critique such an institution is likely to attract. Scrutiny from external actors may improve the quality of justice provided, at least in healthy institutions that are reflective, self-critical and open to outside monitoring and assessment. For other forms, ADR will only be accessible through an institution, for example, an ombudsperson-style investigation or a quasi-judicial body. Moreover, if the purpose(s) of resolving a particular dispute extend to addressing systemic practices, changing behaviours and guaranteeing non-repetition, an institutional approach will be important in order to identify and address wider human rights issues.

At the same time, a decision to vest an institution with an ADR mandate for human rights complaints is not necessarily neutral or solely about increasing accessibility and optionality in dispute resolution. Even if not intended, it is likely to have the effect of promoting and centralising the form(s) of ADR as a key means to resolve human rights disputes. This is potentially to a greater degree than would have been the case if the availability of the form(s) of ADR was dependent on engagement by individual complainants and their legal advisors or representatives. The institutionalisation of ADR for human rights complaints could therefore involve a shift from recognition of the permissibility of voluntary engagement of ADR for human rights complaints in certain circumstances, to normative promotion of that form(s) of ADR as a central means of resolving human rights complaints. In this part of the article, we first assess these risks before proposing ways in which they might be mitigated in order for the institutionalisation of ADR to contribute to an enhancement and pluralisation of access to justice in human rights cases.

\subsection{From Optionality to Mainstreaming: Risk of Transformation into Quasi- Mandatory}

The perceived voluntariness of ADR will be affected by how accessible the courts are. In an ideal world, individuals with human rights complaints would be able to access free legal advice and then legal aid for adjudication or ADR in order to ensure that they had a choice of the route most appropriate and suited to their needs and the nature of the complaint. 
However, the reality is that an institution with an ADR mandate is likely to function within an environment in which the availability of legal aid is limited, particularly in the civil and administrative justice spheres. In such a context, the lack of legal aid may be a key barrier to complainants who wish to bring a claim for an alleged violation of a human right before the courts or seek judicial review of a decision of the executive that affects their rights. It may also mean that access to legal aid is only available for certain types of violations, such as torture, but not a housing complaint thus creating a division in access to justice that is contrary to the universality and indivisibility of human rights. ${ }^{66}$ Without legal aid, complainants may only be able to access the courts if they can self-represent; if law firms offer no-win, no-fee arrangements; or if an organisation such as a non-governmental organisation or NHRI has capacity to carry out strategic litigation and views the claim as raising a wider issue that if successfully challenged, would lead to a change in law, policy or practice and thus benefit a wider group within society.

If an institutionalised form(s) of ADR is introduced or available in such a context - even if voluntary on its face - it may be seen as the main vehicle to access justice, particularly if free ${ }^{67}$, and thus become the norm rather than an option suitable for some but not necessarily all human rights complaints or complainants, turning it into a de facto mandatory process. While ADR may have particular attributes such as creativity in remedies, where it is the only real avenue to pursue a complaint in practice, these features may be diminished. ADR may then be seen as the cheaper but lesser dispute resolution option thereby appearing to create a two-tier system based on affordability.

Institutions with an ADR mandate therefore need to be aware of their potential impact on the wider dispute resolution landscape. In this type of context uptake will not solely be decided on the basis that the process is the most suitable for the complainant, alignment with the aim(s) of pursuing a human rights complaint and the type of dispute at issue. Institutions such as NHRIs should approach its incorporation with a mind to the possibility of ADR 'creep' and the need to make conscious decisions about whether the form(s) of ADR should develop into a central means to resolve human rights complaints. This is particularly the case as the institutionalisation of ADR may open the way for policymakers to later view the increased use of ADR (driven by the relative accessibility of courts and availability of legal aid) as an

\footnotetext{
${ }^{66}$ Ernst-Ulrich Petersmann, On 'Indivisibility' of Human Rights, 14(2) EUR. J. INT'L L 381 (2003).

${ }^{67}$ Interviewee 60.
} 
opportunity to convert a voluntary system into a mandatory system by first requiring parties to try to resolve the complaint through the ADR process before or instead of bringing a complaint before the court or being eligible for legal aid. It could also eclipse efforts to address shortcomings in funding for access to justice through other routes and detract from or ossify wider efforts to reform the legal system. ${ }^{68}$

\subsection{Mitigating the Risks}

In response to these risks, one option might be to reject the institutionalisation of ADR for human rights related disputes on the grounds that it is likely to become the main form of dispute resolution, even if voluntary, particularly in the face of legal aid cuts. The problem with this approach is that it means that many complainants may have no means to access any form of justice and some claims may be suited to the ADR process, as already noted.

An alternative approach may be to examine how the institution might both fill a gap in the access to justice landscape but equally develop an evidence base for the need for other types of processes for accessing justice, where lacking, and increased legal aid, either separately or through vesting the institution with additional powers. ${ }^{69}$ For example, in its 2015 annual report, the Macedonian NHRI (an ombudsperson) noted that '[s]ome of the citizens, although informed of the fact that the Ombudsman is not competent to act, due to their material position, and the impossibility to engage a lawyer, are still addressing the Ombudsman. Having this situation in mind, the Ombudsman repeated the position from last year, that is, recommended the strengthening of the system for free-of-charge legal assistance'. ${ }^{70}$ Thus, the approach would be to analyse and document complaints received that the institution considers inappropriate for treatment through the form of ADR offered and where no other way to access justice exists. In taking such an approach the institution would need a database and system for analysing the complaints it receives as well as external evaluations to assess the appropriateness and effectiveness of the ADR process for human rights.

\footnotetext{
${ }^{68}$ HAZEL GENN, JUDGING CIVIL JUSTICE (2010).

${ }^{69}$ The importance of this type of approach is illustrated by Article 31 of the UN Convention on the Rights of Persons with Disabilities which requires states to 'collect appropriate information, including statistical and research data to give effect to the present Convention'.

${ }^{70}$ Republic of Macedonia Ombudsman, Annual Report on the Degree of Provision, Respect, Advancement and Protection of Human Rights and Freedoms, 2015 (2016) at 139.
} 
In carrying out such an assessment, the first level of analysis would be to document whether or not the institution deems the complaint admissible. Many ombudspersons provide statistics on the number of complaints they reject. ${ }^{71}$ Within this context, a key issue would be to assess whether the complaint concerned human rights and if another mechanism or process exists through which the claimant could seek redress. Where another mechanism does not exist, this would provide evidence of an access to justice gap. Equally, the scale of work involved and significant resources required is important to note as discussed later.

A second level of analysis would be to assess whether the particular form of ADR is appropriate to resolve the particular human rights claim. For example, an institution with a mediation function may find that the form of ADR it offers is not suitable for certain types of claims, for certain complainants, where cases are particularly complex or the law uncertain or where the purpose(s) of pursuing a complaint relate to guarantees of non-repetition or systemic change. Similarly, the investigatory powers of an ombudsperson may be suitable for dealing with certain types of human rights complaints but not others depending on its resources, approach to investigation and powers. The governing statutes of some ombudspersons suggest that certain types of complaints should only be dealt with by a court although not all provide a clear indication of which types of complaints would fall within this category even if these types of determinations are made in practice ${ }^{72}$. The legislation of the Human Rights Defender (an NHRI) in Armenia provides that, '[t]he Defender shall not consider those complaints that must be settled only by Court ${ }^{73}$... the Defender shall by his own initiative make a discretionary decision about accepting the issue for consideration, particularly in cases when there is information on mass violations of human rights and freedoms, or if these violations have exceptional public significance or are connected with the necessity to protect the rights of such persons who are unable to use their legal remedies' ${ }^{74}$

Where the institution deems that its ADR functions are not appropriate for dealing with the particular type of human rights complaint, the institution may be able to map whether another means of accessing justice exists as well as propose the types of processes that it deems suitable for the type of complaint at issue. Such an approach may strengthen the case for

\footnotetext{
${ }^{71}$ See for example, 2015 Annual Report on the Results of the Activities of the Institution of the Human Rights Ombudsman of Bosnia and Herzegovina (2016) at 145.

${ }^{72}$ Interview 118.

${ }^{73}$ Article 10 of The Law of the Republic of Armenia on the Human Rights.

${ }^{74}$ Id.
} 
enhancing legal aid as well as support the proposition that other forms of ADR are also needed. For example, an institution with a mandate to offer conciliation might make the case for a mandate to carry out ombudsperson-style investigations in order to enhance its factfinding capacity. Vice versa, an ombudsperson may make the case for more formal agreement-based ADR powers in order to try to resolve cases prior to initiating a formal investigation. Both might also make the case for litigation powers where cases are not successful or for other institutions to which cases appropriate for litigation might be referred.

This type of approach would also enable the institution to evidence the areas in which the development of the law stagnates as well as identify cases that would serve as test cases and any that could not be taken forward due to a deficit in legal aid. The institution could also document the options for enforcing agreements or recommendations issued by ombudspersons as well as to judicially review the decisions of the ADR process itself. Provision for judicial review is of key importance to warrant against the risk that some ombudspersons might decide not to take up cases which they see as politically sensitive. ${ }^{75}$

As far as we are aware, where ADR is already available in institutionalised form for human rights complaints (such as within an NHRI or an ombudsperson with an explicit human rights mandate), the type of documentation and monitoring we envisage here is not routinely carried out. It is particularly challenging as it requires a reflexive approach and for institutions to identify their own limitations. It would also require significant resource and a sophisticated assessment of the types of claims and complainants suitable to particular processes that did not revert to reductive assumptions that low value claims or ones involving certain economic, social or cultural rights are appropriate for ADR whereas civil and political rights are not.

These risks and limitations notwithstanding, such empirical evidence would be transformational in establishing and evidencing the strengths and advantages of institutionalised ADR in certain cases for human rights complaints as well as establishing the boundaries and limitations and where legal aid for litigation is critical. It would thus focus on mitigating ADR being considered a second-best option for access to justice in climates

\footnotetext{
${ }^{75}$ ROBERTO GARGARELLA ET AL, COURTS AND SOCIAL TRANSFORMATION IN NEW DEMOCRACIES: AN INSTITUTIONAL VOICE FOR THE POOR? (2006).
} 
without adequate legal aid provision while opening up the possibilities for access to justice and a more plural and fuller dispute resolution environment.

Where institutionalised ADR is identified as a potential means of addressing gaps and deficiencies in access to justice for human rights complaints, a detailed and forward-looking impact assessment will be needed to determine the impact the ADR process - even if voluntary - might have on the wider access to justice landscape in order to determine whether this is normatively desirable. We would suggest that this type of assessment might also be carried out where institutions already provide a form of ADR to assess the effectiveness of the process and how it connects to other means of accessing justice within a state, including the courts. These questions will involve many of the issues discussed above on whether ADR is permissible but assume a different tone and focus when asked in relation to normative promotion and the impact on the wider access to justice landscape.

\section{Which Institution Should be Vested with an ADR Function?}

Provided the issues identified in Parts 1 and 2 can be addressed, the final point for consideration is which institution should be vested with an ADR function for human rights complaints. As already noted, a role for NHRIs in complaints-handling (including but not limited to ADR) is envisaged but not required by the Paris Principles. ${ }^{76}$ Bodies such as the UN Office of the High Commissioner for Human Rights and the ICC/GANHRI have subsequently promoted such a role for NHRIs as part of their mandate to protect human rights and many NHRIs offer some form of ADR. At the same time, NHRIs take many different forms and other institutions may exist that could offer ADR for human rights complaints, making the identification of the appropriate institution more complicated than may initially appear. In the final part of this article, we identify key factors to take into account when assessing the optimal institution to offer ADR for human rights complaints.

\subsection{Focusing on the Most Effective Institution to Provide ADR}

\footnotetext{
${ }^{76}$ Principles Relating to the Status of National Institutions UNGA Res 48/134, UN Doc.A/RES/48/134 (1993); See, also Rachel Murray, National human Rights Institutions: Criteria and Factors for Assessing their Effectiveness, 25(2) NETHERLANDS QUARTERLY OF HUMAN RIGHTS 189, 201 (2007). See also ICC/GANHRI, General Observation 1.10, supra note 15.
} 
In the majority of jurisdictions, it is likely that one or more institutions already exists that provides - or could provide - ADR for human rights. In Europe, in particular, which was the focus of our study, one interviewee noted that multiple services and agencies may already exist, meaning that 'you are already dealing with contexts that are so dense in terms of existing frameworks that [NHRIs] are de facto constrained as to the kind of space that they can occupy', ${ }^{77}$ This can lead to the assumption that as institutions already exist that could deal with complaints, they should handle human rights complaints. Such institutions include ombudspersons, inspectorates, state agencies and civil society organisations offering advice, representation and/or direct ways in which to resolve complaints as well as specialised human rights bodies such as equality bodies and children's commissioners. ${ }^{78}$ Indeed, within the course of our research, a number of NHRIs noted that they had not been vested with a dispute resolution mandate as that would have meant overlap with the ombudsperson. ${ }^{79}$

Equally, some NHRIs are also ombudspersons but may not have other ADR functions such as mediation or are also equality bodies with an existing ADR process for discrimination complaints, for example. Therefore, they may be part of an assessment of whether their mandate should be expanded. There are important reasons why expansion of the mandate of an existing institution should be considered. For example, if there is already a body, such as an ombudsperson, with an ADR function, there may be a risk that a specialist human rights body duplicates its work and creates confusion for individuals seeking to lodge a complaint. ${ }^{80}$ On this view, the focus should be on avoiding multiple points of entry for complaints in order to offer a consistent and coherent approach and prevent complaints falling through the gaps.

However, even where another institution with an ADR function exists that could or already deals with certain types of human rights complaints, the assumption should not automatically be made that it is best placed to do so. Rather, the focus, in our view, should be on ensuring that the institution(s) that can provide the most effective means for resolving human rights complaints, including addressing the provisos made in Parts 1 and 2 of this article, have an ADR mandate for human rights complaints. As one interviewee within our research noted,

\footnotetext{
77 Interview 9; Interview 54.

${ }^{78}$ Crowther and O'Cinneide supra note 20 at ii. Peter Rosenblum, Tainted Origins and Outcomes, in RYAN GOODMAN AND THOMAS PEGRAM, HUMAN RIGHTS, STATE COMPLIANCE AND SOCIAL CHANGE: ASSESSING NATIONAL HUMAN RIGHTS INSTITUTIONS 322 (2012).

${ }^{79}$ Interviews 4 and 5; Interview 55; Interview 23. Expert Meeting on the Role of National Human Rights Institutions in Providing Access to Justice, 21 September 2015, Wivenhoe House Hotel, University of Essex ${ }^{80}$ Interview 53.
} 
the risk is that in states with relatively well functioning judicial systems, policy-makers may only focus on what is formally available rather than effectiveness in practice. ${ }^{81}$ However, even in situations in which options for accessing justice appear to be available, they may not be as complete or as effective as one might initially assume and there may be gaps.

Part of this assessment will involve analysis of the quality of justice provided by existing institutions and, where deficiencies exist, whether it is better to try to strengthen the quality of justice within existing institutions or create a new service. A key issue within this analysis is whether the complaint is explicitly dealt with as a human rights complaint by, for example, using IHRL to assess and guide the resolution of the complaint as well as ensuring that substantive and procedural justice standards developed for the particular form of ADR are in place. ${ }^{82}$ This type of assessment does not appear to be regularly undertaken - and was one of the hardest issues on which to collect data in our research-but is critical if ADR is to offer a form of effective remedy for human rights complaints.

\subsection{The Preferred Location within a Body Expert in Human Rights}

Given the lack of consistency and practice on ADR generally and its relative youth in dealing with human rights complaints, there are particular reasons that a body with a human rights mandate might be preferred. The most obvious point is that a body such as an NHRI is likely to have substantial expertise in IHRL and thus be able to assess the extent to which settlements, recommendations and forms of reparation comply with IHRL. ${ }^{83}$ One might also assume that an NHRI would incorporate or be open to developing substantive and procedural standards of justice and adopt a human rights-based approach to the ADR process ${ }^{84}$ thus responding to some of the risks identified in Parts 1 and 2 of this article.

\footnotetext{
${ }^{81}$ Interviews 9; 43.

${ }^{82}$ See Part 1 of this article.

${ }^{83}$ UN Principles supra note 30.

${ }^{84}$ Scottish Human Rights Commission, PANEL Principles available at: http://www.scottishhumanrights.com/inpractice/human-rights-based-approach/ (last visited 31 January 2017) and the Northern Ireland Public Services Ombudsman and Northern Ireland Human Rights Commission, Human Rights Manual (2016). See, Lorna McGregor, Rachel Murray and Shirley Shipman, 'First Contact with Complainants: A Human Rights Based Approach to Triage and Referrals by NHRIs' (April 2017).
} 
If well-known and trusted, NHRIs and related bodies may also be in a strong position to reach persons in positions of vulnerability or hard-to-reach sections of the community, ${ }^{85}$ particularly by playing a mediating role between minorities and the state with regard to access to state services in situations where there may be a 'a level of distrust between members of the population [such as minorities facing longer-term disenfranchisement] and state bodies, this is where NHRIs and ombuds offices can be really the only possible body where you can have an interface with certain sections of the population' ${ }^{86}$

NHRIs may also be well-placed to address concerns about the public interest, accountability and guarantees of non-repetition addressed in Part 1, particularly where they have a strong link between complaints-handling (which may include ADR but also encompass advice, assistance and representation) and documentation and reporting on patterns of human rights violations. Within our research, interviewees noted that complaints-handling (including ADR) could feed into the strategic human rights work undertaken by NHRIs and enable them to identify trends and groundswells. It would also provide a means to identify underreporting on issues on which one might expect to receive complaints which could then be investigated and outreach conducted by the NHRI.

However, there is a risk that complaints-handling does not feed into systemic issues. One interviewee one participant at the expert meeting we convened as part of this research noted that in his experience, complaints mechanisms may not be particularly helpful in addressing systemic issues. ${ }^{87}$ Where this occurs, it may be due to a lack of process internally to analyse the nature of complaints and the extent to which they are indicative of human rights concerns in the state and/or low levels of complaints from certain groups or sections of society as well as resource constraints and inadequate funding. Indeed, the complaints-handling function of an NHRI can often be quite separate from its wider promotional and protection work. In this respect, where an NHRI has an ADR function, it is critical that it puts a system in place to analyse complaints and complainants.

\footnotetext{
${ }^{85}$ Obiora Okafor and Shedrack Agbakwa, On Legalism'. Legalism, Popular Agency and "Voices of Suffering": The Nigerian National Human Rights Commission in Context, 24(3) HUMAN RIGHTS QUARTERLY 662, 695 (2002).

86 Interviews 4 and 5.

${ }^{87}$ Expert meeting supra note 79.
} 
From an institutional perspective, the adoption of at least some form of complaints-handling may enhance the perception of the accessibility and relevance of an NHRI, particularly with the general public thus providing institutional benefits. ${ }^{88}$ Equally, it might be argued that other means of enhancing such perceptions exist, for example through national consultations, advocacy work and thematic inquiries. The extent to which other functions have the same impact in terms of increasing the credibility and visibility of an NHRI is difficult to measure and will depend in part on the context in a specific jurisdiction. Nevertheless, the ability of individual members of the public to approach an NHRI with a complaint and potentially have that complaint investigated and/or for the NHRI to try to find a solution to resolve the case has been cited as an important element in determining the effectiveness of an NHRI. ${ }^{89}$

\subsection{Challenges for NHRIs Playing a Role in ADR}

Even though a body with human rights expertise may appear to present the optimal institution to vest with an ADR function, there are a number of challenges to an NHRI or similar body playing such a role that also merit consideration and again depend to a large extent on the type of NHRI concerned and its existing powers. For example, an NHRI that is also an ombudsperson raises very different questions about ADR to a traditional human rights commission with no existing ADR (but potentially advice, assistance or representational) role. In this final part, we identify the type of challenges that can arise for NHRIs assuming an ADR (or complaints-handling) function.

\subsubsection{Dividing complaints}

First, human rights bodies are only likely to be vested with a mandate to deal with the human rights dimensions of the complaint unless they are organised within an umbrella body with a wider subject-matter jurisdiction such as an ombudsperson. ${ }^{90}$ In some cases, this will not raise any issues. However, there may be dimensions to the complaint beyond human rights rendering it necessary to split the complaint between two bodies. For example, the Canadian

\footnotetext{
${ }^{88}$ Interview 2.

${ }^{89}$ Commonwealth Secretariat, supra note 13 at 3 .

90 This will not be the case with all NHRIs. For example, some NHRIs that are also ombudspersons can deal with the wider dimensions to the complaint and not just the human rights aspects.
} 
Human Rights Commission can only deal with complaints on discrimination. ${ }^{91}$ Where it receives a complaint that raises issues beyond its subject-matter jurisdiction, it has to refer these aspects to another body.

\subsubsection{The Compatibility of the Promotional and Regulator Function}

Second, some interviewees argued that an NHRI with an ADR function must act with neutrality in fairness to both sides to the dispute. ${ }^{92}$ Interviewees questioned whether an ADR function produces a tension - and possible conflict - between an NHRI's mandate to promote human rights (which they argue necessarily requires it to act as an advocate) and the need to preserve a position of neutrality in dispute resolution. ${ }^{93}$ One NHRI noted that 'even if mediation would be mentioned in the law, it would be difficult to envisage how this would be done in practice since the people in our office are not necessarily considered as neutral. The office is considered as a 'saviour' by the people'. ${ }^{94}$ Another interviewee from an NHRI noted that it 'constantly struggle[s]' with this issue as 'every time a respondent comes to us, they will think that we already have a view on the complaint'. ${ }^{95}$ One interviewee noted that the tension would not arise where the NHRI provides advice, triage or represents individuals in ADR processes or before courts as these functions would align with the promotion and protection of human rights ${ }^{96}$. This concern is echoed in a study of equality bodies within Europe. Crowther and O'Cinneide note that 'integrated bodies [meaning bodies that have a dual mandate such as an ombudsperson and NHRI] can also face particular difficulties in circumstances where they are expected to function both as an active and engaged agent of social transformation and as an enforcement and regulatory agency charged with securing compliance with established equality and human rights standards'. ${ }^{97}$

The tension is not necessarily insurmountable but requires assessment and management and may speak in favour of an NHRI working with another body to develop its ADR capacity in a

\footnotetext{
${ }^{91}$ Canadian Human Rights Act, Part III.

92 Interview 14.

93 Interviews 14; 43.

${ }^{94}$ Interview 118.

95 Interview 63.

96 Interview 14.

${ }^{97}$ Crowther and O'Cinneide, supra note 20 at 44; Colm O'Cinneide, A Single Equality Body: Lessons from Aboard (Equal Opportunities Commission 2012); Colin Harvey and Sarah Spencer, Advancing Human Rights and Equality: Assessing the Role of Commissions in the UK and Ireland (2012) 35 FORDHAM

INTERNATIONAL LAW JOURNAL 1615 (2012); EQUINET, Equality Bodies and National Human Rights Institutions: Making the Link to Maximise Impact (2011).
} 
human-rights compliant manner rather than assuming it itself. One interviewee noted that the management of firewalls between the promotional work and the complaints-resolution functions would be particularly important as well as solutions such as outsourcing support to complainants within the dispute resolution process in order to avoid perceptions of bias. ${ }^{98}$

\subsubsection{Capacity Concerns and the 'Strategic' Function of Complaints}

Third, embedding an ADR function within an NHRI raises concerns about the range of activities NHRIs are expected to undertake. The Paris Principles and the ICC/GANHRI suggest a wide range of functions for an NHRI which they are increasingly called upon to deliver, including acting as the National Prevention Mechanism under the Optional Protocol to the Convention against Torture and independent mechanism under Article 33 of the Convention on the Rights of Persons with Disabilities. This approach puts NHRIs at risk of assuming - or being required to assume - multiple functions with the result that they are spread too thin. As one interviewee noted, 'the increasing demand on NHRIs is a mirror of multitude of challenges that countries are facing, that have to do with poverty, with human rights, violence' ${ }^{99}$ In such situations, there may be concerns about an NHRI assuming or expanding an existing ADR function, unless the state invests additional resources to enable the NHRI to effectively provide such services. Indeed, it is important to recognise the significant resources needed for quality and effective dispute resolution on a large scale which increases further if thematic and systemic analysis of complaints and behavioural change is also built in.

Within this context, commentators and a number of interviewees within the course of our research questioned whether an ADR function or individual complaints-handling more generally consumes too many resources and distracts from more strategic ways of working directed at addressing the causes or consequences of human rights violations and systemic human rights issues. ${ }^{100}$ This line of analysis led the Scottish Parliament to 'decide[] that it would be better for our [the Scottish Human Rights Commission's] limited resources to be used for working on strategic legal and policy work, instead of providing an advice service.

\footnotetext{
98 Interview 43.

${ }^{99}$ Interviews 4 ; 5.

${ }^{100}$ Interviews 6, 50, 65. David S. Meyer, NHRIs, Opportunities, and Activism, in GOODMAN AND PEGRAM supra note 78 .
} 
This means that we work on human rights issues that affect lots of people, rather than providing advice to a smaller number of individuals' ${ }^{101}$

Some interviewees also noted that dealing with individual cases (including ADR) may not always be the most effective way in which to address major human rights issues. They noted that problems with underreporting may also mean that the complaints made to an NHRI do not always reflect the most pressing issues and that the NHRI is also likely to receive complaints that would not be framed as human rights violations as well as complaints that would have to be referred elsewhere (such as relating to family law). ${ }^{102}$ Some interviewees made this point even in relation to ombudspersons, some of which are now considering whether the processing of individual cases should be replaced or balanced with the introduction or greater use of own-initiatives powers that seek to have a wider impact beyond the individual case ${ }^{103}$ particularly as many ombudspersons are required to investigate all admissible complaints they receive.

By contrast, one interviewee suggested that an emphasis on strategic litigation can 'be an excuse to not deal with all the cases, then complainants have nowhere to go'. The interviewee argued that, "it is important to have a critical mass of casework [and not] assume that there are other places to go as NGOs may be strapped and courts can be deeply inaccessible'. ${ }^{104}$ Another NHRI (ombudsperson) noted that the handling of individual complaints (which can encompass ADR but also advice, assistance and representation) is the "core function if not the only function of the institution'. ${ }^{105}$ In addition, there is a challenge for an NHRI with an ADR or wider complaints-handling function of how to balance its role in identifying and focusing on systemic issues and being perceived as accessible to members of the public on the one hand with, on the other, avoiding being overwhelmed by numbers of complaints.

Where an NHRI does not play a role in ADR (or complaints-handling more generally), in our view, it is important that it has close ties with the institution(s) that do. Similarly, NHRIs that are structured as an umbrella body composed of two or more institutions, one of which provides ADR such as an ombudsperson may require internal links. This would include

\footnotetext{
$101<$ http://www.scottishhumanrights.com/humanrights/helpandadvice> accessed 21 April 2015.

${ }^{102} I d$.

${ }^{103}$ Interview 90.

104 Interview 43.

${ }^{105}$ Interview 116.
} 
referring complaints to that body as well as trying to work with it to try to strengthen its mandate and effectiveness in dealing with human rights complaints. ${ }^{106}$ For example, the Northern Irish Human Rights Commission does not have a complaints-handling function but has worked closely with the Northern Irish Ombudsman to train it and develop a human

rights-based approach to its complaints-handling. ${ }^{107}$ It would also include devising a system of complaints-analysis so that the NHRI could address the wider systemic issues arising from individual complaints. Equally, training and capacity-building may not be enough and a general ombudsperson or an agreement-based ADR process may still require human rights specialists.

The arguments set out here demonstrate that there is no correct answer about the type of institution within which an ADR function for human rights complaints should sit as there are advantages and risks on both sides. These advantages and risks may also weigh differently in different jurisdictions. The key issues however are to ensure that the institution has sufficient resources to provide an effective ADR service for human rights complaints. This may require the investment of additional financial resource as well as new staff with different skills (for the ombudsperson, human rights experts and for the NHRI, ADR experts). In both situations, a critical additional component would be to include resource, expertise and a process to monitor and map the types of human rights complaints that are made against what is known from other sources about the human rights situation in the state and to ensure that they are documented and publicly accounted for.

\section{Conclusion}

In this article, we have sought to provide a framework for decision-making on whether ADR can and should be used to resolve human rights disputes. Our starting point is that engagement with ADR should be voluntary and not seek to undermine or interfere with the duty to investigate allegations of human rights violations, where that duty applies. From there, we suggest that certain forms of ADR may have a valuable role to play in resolving human rights complaints, depending on the characteristics of the process and the objectives in

\footnotetext{
106 Lorna McGregor, Rachel Murray and Shirley Shipman, First Contact with Complainants: A Human Rights Based Approach to Triage and Referrals by NHRIs (April 2017).

${ }^{107}$ Northern Ireland Public Services Ombudsman and Northern Ireland Human Rights Commission, Human Rights Manual (2016).
} 
resolving the dispute. This is particularly the case where parties have an interest in exercising autonomy and pursuing more creative remedies than may be available in court as well as offering scope for dealing with systemic issues. However, in our view, even where the form of ADR aligns with the objective(s) of resolving a particular dispute, the use of the process should be conditional on substantive and procedural standards of justice being embedded within the process. As noted in the article, this is a key area in need of greater reflection and attention if $\mathrm{ADR}$ is to play an effective role in resolving human rights disputes. These standards of justice, however, should not seek to conflate a particular ADR process with courts but rather develop a model that fits the nature of the process.

Institutionalisation of ADR may offer the best prospects for the development of standards of justice as well as enhancing the prospects for systemic human rights issues to be identified and addressed in addition to facilitating individual's right to a remedy and reparation. The article underscores that care must be taken to ensure that institutional provision of ADR does not turn into a de facto mandatory process. In many ways the institution can drive this by being reflexive about the strengths and limitations of its process and identifying where other services (including the courts) are preferable and where gaps remain. However, an institution's ability to do this is heavily dependent on its resources. Further questions also arise about whether an institution should be specialised in human rights, such as an NHRI, or a more general dispute resolution body. In principle, a specialist human rights organisation may offer particular benefits, including on systemic issues. However, as we note in the article, it is rare that these questions will be asked in a context with no existing institutions so in reality, whether a body like an NHRI should offer this role depends, in part, on other institutions that operate within the particular jurisdiction. This in turn impacts on the other functions that the body is expected to undertake, functions which are increasing in breadth and not necessarily matched with additional resources. Therefore, the central question will be whether an institution exists that can offer effective ADR for human rights bearing in mind the considerable resource this will entail. 